across and 24,000 feet deep. Renewed interest is being shown in comparing the geological formations found here on earth and those observed on the Moon. An effort is being made to try and explain the possible ways in which lunar features were formed.

Normally stars are not visible in the daytime. Stars have been seen in the past but these were Nova, stars that increased tremendously in brilliance, later subsiding, to become visible only in a telescope.

Amateur astronomy is never dull. $\mathrm{New}$ performers are constantly making unpredicted appearances. I refer to comets of which as many as a dozen have made their appearance during a year. There is an open season on comets all year round for amateurs. To be the first to discover one is a fine feather in the cap. I also refer to the sporadic meteor showers that cannot be forecast. These can be spectacular, but the time of their occurrence does not always allow us to see them during the hours we normally keep. When the Earth runs into these celestial dust clouds believed to be the remnants of the tails associated with comets, the sky may literally rain meteors, as in 1872 and 1885 when 1,000 a minute were estimated to be visible. A rather impressive display! And remember, a repeat performance could occur any time.

Now what is of interest and what is visible this spring? The Spring Equinox occurs March 20 at 3 p.m., the Summer Solstice June 21 at 10 a.m. The Earth's aphelion or point of greatest distance from the sun is reached July 5 at 1 a.m. Only one eclipse, an eclipse of the Moon, occurs in November.
During the first part of the year Venus will be performing at her best. Greatest brilliancy will occur May 16 in the evening sky. Mars will receive most attention during the latter half of the year. During 1956, Mars will be at its closest to the earth, although appearing somewhat to the south to us northern observers. This spring until June, Mars is visible only after midnight; about the end of July it will rise shortly after nine o'clock (MST). Jupiter, easily recognized from its brilliance, will be near the meridian at dusk during April so it will be visible all spring. Binoculars will reveal four of its satellites and also positively identify it. It is a fine sight, so don't miss having a look while the opportunity is at hand. Saturn, the planet with the ring around it at its equator, will be visible later in the spring, rising before midnight in April. A small telescope will reveal the ring that puzzled Galileo. It will, however, be rather far south in the sky this year and hence difficult to observe.

Still to talk about are the sunspots, Northern lights or Aurora Borealis, interesting stars, and nebulae and star clusters. I have only touched on a few of the things that an amateur can look out for. Why not take a look for yourself? Every clear night a display is brought on stage that defies description, yet so few see the individual members of the cast. I must warn you that if you do become interested in this drama you will be caught up and held by it. You become part of it, yet are left with such a feeling of insignificance! Truly a wonderful place, the universe!

\title{
Bird Watcher or Seer?
}

\section{BOSWELL BELCHER, Dilke, Sask.}

One must have infinite patience and energy for travelling many hours and miles afield with binoculars hunting down new species to be called a good bird "watcher." I have not that patience, but being a farmer, I spend many hours afield and cannot help seeing what is about the fields; I might be called a bird "seer." Now a bird seer gets as much satisfaction out of finding a species his friends have not seen as does a true bird watcher. The inconspicuous
American Pipit gave me that opportunity for a year or so but the enthusiastic bird watcher has now caught up with me. About May 5 or 6 I expect to see again one or two of these sleek and refined-looking birds running about the flats or slough edges on the open fields as I have done every spring since Stuart Houston and my sister Margaret "drafted" me into identifying birds (I always see them when I'm not looking for them as that is the only 
way I ever, find anything - maybe that is the attitude of the "seer," not the "watcher").

Some years ago when I first realized I was seeing these birds every spring I went to the bird book to identify them. I soon jumped to the conclusion they were American Pipits - but, alas, I find one must not jump at conclusions, one must be sure if he wishes his friends to respect his identity of birds. Margaret and Stuart immediately began asking innumerable questions about the birds. In fact, they almost had me convinced that it might be a Sprague's Pipit (much commoner and a summer resident here). But my confidence in my former identification was completely rebuilt when Margaret came home one weekend with the news that George Ledingham sees. American Pipits in the spring on the farm near Moose Jaw. So for a year or so I was one jump (or should I say one bird?) ahead of the bird "watcher." Last spring, however, the infinite patience of the bird watcher enabled my sister to catch up with me. After vainly walking the fields to see American Pipits I had spotted, Margaret rode with me to where I had seen two during my seeding operations that morning. There on a flat in the summerfallow field were the pair of American Pipits. Now I had proved my identity of the birds, but the bird watcher had caught up to me. Whether you are a "watcher" or a "seer" you, too, may "find". or "see' these beautiful sparrow-sized birds come May 5 to 7 if you're in our area.

\section{Entrancing Puzzle - Nature}

\section{By ELIZABETH CRUICKSHANK}

Life is a puzzle, yet we know all the bits and pieces we are privileged to see must fit together to make the magnificent master plan.

We witnessed a Northern Shrike in action this winter when it dropped then recaught a Red-breasted Nuthatch. These little acrobats must consume great quantities of insect pests as they climb up and down the tree trunks; but like the Crossbills they often forage on the tips of the branches becoming easy prey for predators. Saddened as we were to lose the little fellow whose life we shared on our birding jaunts, we knew that this experience was but a tiny bit of life's gigantic jigsaw.

Another piece we saw near the power-house where a company of ducks enjoyed the bread cast on the water by faithful friends. On the ice edge, like a lump of snow sat a Snowy Owl, biding his time.

However, a different spectacle began the New Year. In the quiet of the morning in a corner of the park we stood surrounded by tall evergreens, their outstretched arms heavy with their burden of snow, now sculptured by wind and glazed with light. Sun-bronzed cones of their topmost branches beckoned their feathered dinner guests.
Evergreen and poplar, ermine sheathed, sifted the sunlight which fell in patterns on the glistening carpet of snow, "deep and thick and even." A radiance held the place, something immortally lovely, not just a carryover from the thoughts of the cradle of Bethlehem that seemed at the moment just around the corner. A glory shone round about and peace was in this place at least a reality.

As Bohemians, Grosbeaks, Chickadees, Redpolls, Crossbills, Finches and Nuthatches carolled, each from his own score, we felt the spirit of the infinite composing a symphonic poem for us humbly to interpret and to enjoy. Near the open field a flock of Sharptails flew, their wings strumming an accompaniment to the music that lingered in our hearts.

Along the road a company of Pine Grosbeaks "like twinkling winter lamps among the branches of the leafless trees" were lunching on the samaras still clinging to the ash trees. So near were we that we felt the oneness of small things shared, like the bi aaking of bread together.

On the crabapple tree Waxwings eating the scarlet fruit or resting to hum a little, presented another delayed Christmas card of unbelievable beauty. 